\title{
6 \\ Tracing Storylines
}

This book has explored multiple invocations of educated woman- and girlhoods to argue that discourses on women's and girls' education are often deeply entangled in class, familial, nationalist, and hetero-patriarchal interests. Be it the British colonizers and Muslim social reformers at the turn of the twentieth century, the Pakistani state during the 1950s, or transnational corporations and nongovernmental entities today, a broad range of social actors have participated in articulating ideal performances for women and girls. These articulations often signal anxieties about, and hopes for, distinctive social orders where women and girls are expected to play particular roles, ranging from taking charge of domestic happiness, overseeing the nurturing of future citizens, laboring to advance the economic growth of the nation, maintaining gendered spaces, and reproducing social-class positioning by means of their aesthetics, public piety, and labor participation or withdrawal. The result is a range of subject positions for womensome of which are marked as desirable and others as failed. These include sharif beti, sughar beti, purdah-nasheen, teddy girl, ultramodern girl, modern girl, buri aurat, bazari aurat, student, and empowered girl, among others. As I trace these subject positions, I have elaborated on how they open up as well as close possibilities for women and girls.

I attend to the diverse appearances of the educated female subject in cultural archives, not in order to identify its evolution, but to isolate the different scenes where she engages in different roles. ${ }^{1}$ In some instances, such as at the turn of the twentieth century, we see the ideal educated woman as rearticulating the respectable status of ashraf Muslims through her practices in the domestic sphere. During the 1950s, she enables a fuller articulation of what it means to be Pakistani 
and Muslim by standing in contrast to women who perform excessive piety (the purdah-nasheen) as well as women who are enamored of the West (the ultramodern girls). During this time, she also clarifies what it means to a "modern" subject through her consumption and labor practices. In the contemporary moment, she highlights for us how boundaries of social class are forged in and through women's labor-force participation and marriage. As an upper-middle-class woman, she values education in order to increase her marriageability and shows a clear preference for the home where she can nurture the next generation. Her lowmiddle-class counterpart, however, values education to enter the workforce but seeks to identify professional spaces that might preserve a semblance of middleclass respectability. They both attempt to preserve their class status by distancing themselves from poor and lower-class women who must engage in menial labor, as well as the wasteful ultrarich. In forging these diverse woman-girl-subjects, the question of education seems to always be about the kind of orientation that women and girls are to have in relation to themselves, their families, waged work, and the nation.

Significantly, across the three periods we observe a repetition of discourses with difference. As Gilles Deleuze notes, "to repeat is to behave in a certain manner, but in relation to something unique or singular which has no equal or equivalent." ${ }^{2}$ For instance, notions of respectability emerge across all moments taken up in this book but signify different kinds of relationships between women and capital, women and the nation-state, and women and the patriarchal family. This translates into different possibilities and limitations for women and girls. Likewise, while education is invoked across all three moments, the institutions and actors that the discourse authorizes are quite different. In this concluding chapter, then, I tease out such themes and view them as overlapping storylines. I trace shifts and patterns across the three moments taken up in this book with the hope of signaling the systems of power within which these stories take shape. Indeed, a genealogy does not tell one grand story, rather it traces overlapping storylines.

\section{TRANSMUTATIONS OF RESPECTABILITY}

One of the enduring themes in this book is in relation to respectability (sharafat). Women's practices seem to be a key discursive space through which respectability is expressed. This book, however, shows that concerns about respectability are often closely linked with efforts to forge a class identity. In other words, social class is often expressed and consolidated through expressions of sharafat, which are in turn conveyed through women's practices. This includes women's performances of piety, domestic management, movements/mobility, as well as consumption patterns. Respectability, then, is a name given to a collection of performances that signal class status. Education appears as both a social project that can direct women 
toward desired performances, and a commodity (such as English-medium education in contemporary Pakistan) whose consumption signals class status. Thus, one of the storylines in this book relates to the endurance of class concerns, which manifest themselves through the idiom of respectability.

At the turn of the twentieth century, calls for Muslim women's education were intricately linked with the shifting social, economic, and political landscape of Muslims in South Asia. Under the Mughal rule, privilege in the form of access to resources, administrative positions, and stipends accrued to ashraf Muslims, a social category that included the descendants of Arab, Persian, Turkic, and Afghan ethnicities. Others who earned their living through scholarship and erudition were also part of this social class. Being a member of this social class signaled one's noble and respectable status. However, by the turn of the twentieth century, with the administration securely under the British, the privileges that members of this class enjoyed were on the decline, and ashraf Muslims of North India and Punjab had to adjust their economic and social lives to the new regime. Respectability could no longer be asserted on the basis of one's familial background or ethnicity, as the nobility no longer enjoyed control of resources and labor. This opened up the space for the assertion of new forms of respectability.

One such effort entailed dissociating respectability from ethnicity and attaching it to social practices and aesthetics, such as domestic management, proper Muslim rituals, and elementary reading and writing skills. Such characteristics made sharafat accessible to social groups, such as merchants and traders, who previously had been excluded from this category. Similarly, the opportunity to be a part of the British bureaucracy and gain economic prosperity also created the possibility for class elevation for the professionalizing social groups. Women emerged as a means in and through which this new definition of respectability was forged. They were to be educated in specific ways so that they would display the right kinds of cultural dispositions and behaviors that would be constituted as respectable. Education thus allowed for the cultural reproduction of the new ashraf social class.

It would, however, be naive to assume that this transformation was uniform. In fact, in chapter 2, I have traced the diverse views about what constituted sharif womanhood and girlhood and the role of education in cultivating these subjects. While some social reformers called on women to reform their religious practices by avoiding superstitious customs and becoming experts at house management and childrearing, others envisioned a role for women as generators of income and began to imagine women as individuated selves. The different orientation toward waged work is a reflection of the economic anxieties experienced by some members of the ashraf social class. Thus, the content and spaces for women's education came under intense scrutiny as different segments articulated their own visions for the kinds of transformations that education should bring about in women in order to display sharafat. Evidence from novels as well as women's magazines shows that 
women, too, participated actively in these conversations and were as equally varied in their opinions as men.

For the new ashraf women, khana-dari (household management) emerged as a domain where they could enact a distinctly educated version of themselves. Readers will recall Muhammadi Begum's texts Sharif beti and Hayat-e-Ashraf, both of which provide excruciating details of how young girls and women are to reshape themselves into ideal wives, mothers, and domestic managers. However, there was also a recognition of the tough economic times that lay ahead for Muslims. The texts called on women to acquire skills that could be monetized during times of difficulty. This included hunar such as sewing, as well as the possibility of setting up maktabs (small, informal schools) at home. Indeed, Sughar beti illuminates what such a life in economic precarity might look like. Here, a sharif family undergoes severe financial constraints and the daughter has to take up the task of making an income, while keeping true to the norms of her social class, in particular maintaining purdah. Bibi Ashraf's story is yet another example of a woman who figures out a way to survive financially while adamantly reproducing norms of gender segregation and preserving her family's claims to sharafat. These novels signal the emergent ties between familial respectability and women's practices.

In the early decades after the political independence of Pakistan, the state became yet another entity that framed respectable womanhood/girlhood. From the perspective of the state, the ideal educated woman/girl was one who contributed to the nation's modernization and development project, either through participation as labor or as a scientifically inclined mother, nurturing the next generation of citizen-subjects. Since, during this period, questions about what constituted a "Pakistani" citizen were closely linked with the role of Islam, women's religious practices came under intense scrutiny as well. Excessive performances of religiosity, particularly those that kept women away from the workforce or the nation's new industries and consumer products, were looked down upon. Likewise, westward orientation, too, was deemed inappropriate. In short, the ideal educated female subject was one who engaged with the institution of religion in ways that did not hinder the homogenizing and modernizing project of the Pakistani state. What is crucial to note is that this educated female subject is also a classed subject; access to education, consumer products, and professional jobs was often only available to members of upper and middle social classes.

The close links across education, respectability, and social class continue to the present. Participants in my focus groups from low-middle-class families aspired to reach middle-class status. They went to school in order to obtain "office jobs"-a code for jobs that were deemed acceptable for middle-class women. This often included jobs as teachers, program officers, secretaries, and so on. The assumption was that women can shield themselves from sexual harassment in these contexts; an assumption that often proved to be incorrect. Any other job-manual labor, in particular-would automatically mark the girls as belonging to lower 
socioeconomic strata. In contrast, participants from upper-middle-class backgrounds wanted to acquire an education primarily to prepare for their future roles as wives and mothers and to enhance their marriageability. They were willing to work only during financially precarious times. For members of this social class, working outside the home was a definite marker of a decrease in familial status, and hence a threat to respectability. This reasoning is visible in Mirat-ul-uroos (2012), where Aima has to work in order to provide temporary respite to male members of her household, but she insists on quitting her job as soon as her husband is able to obtain one. When Aiza wants to work for personal pleasure and fulfillment, her husband does not support her, noting that her primary responsibility is to her home. Upper-middle-class families thus signal their status and respectability through the lack of women's need to enter the workforce. Alternately, women who do enter the public sphere signal non-elite status, which makes them susceptible to harassment and exploitation. The public space in Pakistan thus continues to be marked as masculine, and respectability politics limit a possible transformation of the space in favor of women.

\section{THE EXPANSION OF MODERN SCHOOLING}

This book traces how the institution of the modern school, with its systems of learning, bureaucratic administration, and examinations, gradually becomes the hegemonic institution for educating young people. The expansion of modern schooling has displaced the multiple community-centered educative spaces that were prevalent in colonial India during the nineteenth and early twentieth centuries. Education of ashraf women during that time, for instance, included the study of seminal Arabic and Persian texts, reading and writing skills, learning of hunar such as sewing and cooking, as well training in ethics. The home was viewed as the primary pedagogical site, where multiple actors, such as mothers, fathers, ustanis, and maulvis, performed the duties of educating the young. Writers in women's periodicals often used the phrase talim wa tarbiya (education and nurturing) to denote these wide-ranging purposes of education. These educative arrangements were no doubt meant to reproduce the privilege of the ashraf social classes. Familiarity with Persian and Arabic texts, for instance, signaled the non-Indian origins of the ashraf families. The British model of schooling disrupted some of these social functions of education and replaced them with new hierarchies. It was now English schooling that would confer upward mobility through access to British administrative apparatus and exposure to Victorian norms.

By the 1950s, the school, rather than the familial home, emerged as the primary site for education and moral instruction, leading to intense debates around curriculum, language policies, and dress codes. These debates were not only about changing social-class dynamics but also, crucially, about who would have the authority to engage in the ethical and moral instruction of young women (and 
men). Hence, the debates were often framed in terms of the fear of Christian proselytizing in English schools.

With the global entrenchment of the modern school as the primary social institution for the education of the young, debates around where girls should be educated are becoming largely irrelevant. The current concerns in the field of international development are around getting girls into schools; there is little to no discussion about the sort of learning that is offered in schools, nor an investigation into alternative, viable models for education. However, this does not mean other social institutions, such as the family and the religious community, have given up their claims over molding the young generation. Instead, there continues to be a robust discussion about the moral instruction of youth in postcolonial contexts such as Pakistan. These contestations are visible in the periodic tensions around curricular choices and language of instruction that have erupted in recent years, the development of parallel formal and informal tracks of schooling such as the madrasas, as well as the continued use of ustanis and maulvis for the teaching of the Quran at home. As shown in chapters 4 and 5 of this book, schools are marked as being useful only for credentialization and obtaining jobs. Through the discourse on tarbiyat (upbringing and nurturing), the home is recentered as the ideal environment for moral instruction. This entails engendering ideal dispositions in young people, including educating them in ethics and religion (as was depicted in both the HUM and Geo TV productions). In the process, mothers continue to be considered as ideally placed to produce future citizens. Such a womanhood, as should be clear by now, can only be performed by upper-middle-class women who can rely on the incomes of their male relations. Thus, the recentering of the home as the site for moral instruction also props up particular conceptualizations of mothering, which call on women to depend on men, and in the process, strengthen male domination.

\section{FROM MUSLIM WOMAN/GIRL TO MUSLIM GIRL}

Whereas during much of the nineteenth century it is the composite figure of the Muslim woman/girl who is to be civilized, rescued, and educated, this figure gets disaggregated over time into the figures of the Muslim woman and the Muslim girl, with the latter rising to dominance as the ideal site for reform and rescue by the turn of the twenty-first century. This shift from an all-encompassing Muslim feminine figure to the Muslim girl/Muslim woman takes shape in the context of the rise of mass schooling as well as the peculiar preoccupation of the international development and aid regime with the figure of the girl, as explained in chapter 4. In tracing this shift, I show how gender categories are (re)made and how they function across multiple discursive fields. Understanding the construction of gender categories and their impact is crucial because the figures of the Muslim woman and Muslim girl are increasingly invoked not only within the development 
and aid regime but also in foreign policy discourses, particularly in relation to countering violent extremism (CVE). We, therefore, have to sharpen our analytics to understand how these categories are being used, what kinds of affective histories and collective assumptions they draw on, and how their current deployment is closely tied to these affects.

The rise of the girl is an effect of a number of related trends, some of which I discussed in chapters 1 and 4, such as the ascendency of human capital theories, which see "girls" as untapped labor. However, there are additional shifts in relation to conceptualizations of Muslim women that are at play when it comes to the attention focused on Muslim girls. First, over the last few decades, feminist scholars have launched a robust critique of the trope of the "oppressed brown woman." This includes a number of ethnographic studies that illuminate the complex lives of Muslim women, including their agentic negotiations with local forms of patriarchy, as well as a critique of political and military interventions in Muslim-majority nations. The works of scholars such as Lila Abu-Lughod (Egypt), Saba Mahmood (Egypt), Fida Adely (Jordon), Ayesha Khurshid (Pakistan), and Lara Deeb (Lebanon), among others, are examples of such interventions. This scholarship is accompanied by a rise in Muslim women's organizations that deploy non-Eurocentric idioms to call for justice and empowerment. This includes women drawing on the Quran and Muslim legal traditions to call for reforms in their societies. Together, these trends cast doubts about Muslim women's apparent silent status.

Second, the figure of the "Muslim woman" is increasingly being cast as suspect, making way for the "Muslim girl" to emerge as a competitor for the salvific rhetoric previously associated with Muslim women. While stories about Muslim women's complicity with "terrorists" have always circulated-such as during the Algerian revolution-it is only recently that Muslim women are being portrayed as embodying the same type of "threat" that Muslim men have represented for a long time. Consider the media coverage of Chechen Muslim women's actions during the Chechen-Russian conflict in the 1990s. Sara Struckman observes that Muslim women were primarily characterized as passive victims. ${ }^{3}$ However, when they started to participate in suicide bombings their articulation moved to vengeful actors- "Black Widows." Later, when it was found that women did not act simply to avenge the death of male relations, it was believed that they were coerced by Islamic extremists who drugged or raped them on video and, hence, compelled them to carry out attacks against their will. Such explanations obfuscated these women's political agency to fight for Chechen independence. More recently, however, with the rise of Daesh globally, women's agency in enacting antistate and antiwestern attacks has been more centrally recognized. Earlier, in 2008, we learned about Samina Malik, from the United Kingdom, who called herself the "lyrical terrorist," writing poetry about beheadings. In 2010, Roshonara Choudhry stabbed a British MP, explaining that she did so because he had voted to send British troops to Iraq. There is, then, a steady portrayal of Muslim women as new suspects and a new threat. 
The ascendency of the figure of the "female jihadist" is a case in point. The term is often used to describe Muslim women who have launched attacks in western contexts, most recently in California (December 2015) and Paris (November 2015). The female jihadist is viewed as abject and dangerous, an intimate threat. Consider the case of Tashfeen Malik, who along with her husband, Syed Rizwan Farook, opened fire during a party and training session at the Inland Regional Center in San Bernardino County, California, killing fourteen people and wounding twenty-four others. In the aftermath of the event, extensive interest emerged in Tashfeen's education and background-as the headline in Reuters noted: "Female attacker stands out in California mass shooting." ${ }^{4}$ There was interest in finding out what had transformed her from a "happy bride to [a] shooter." ${ }^{5}$ Exclusive feature articles that attempted to piece together her life in the United States as well as abroad, particularly in Pakistan and Saudi Arabia, appeared in major newspapers. For instance, the New York Times featured an article entitled “Tashfeen Malik, San Bernardino Suspect, Attended Conservative Religious School in Pakistan," ${ }^{6}$ which explored potential connections that Tashfeen may have had with an educational institute, Al-Huda Center, in Multan. Drawing connections between religiosity and violence, the article notes: "critics in Pakistan have long accused Al Huda, which urges women to cover their faces and study the Quran, of spreading a more conservative strain of Islam. But it has never been directly linked to jihadist violence. Still, confirmation that Ms. Malik had studied with the group offers a new clue to her disposition in the years before she left Pakistan for the United States."7 Clearly, her education in Pakistan and upbringing in Saudi Arabia were seen as pivotal moments in transforming her into a "jihadi." Tashfeen has also been portrayed as an autonomous subject, an articulation that has normally not been afforded to Muslim women. Speaking of Tashfeen, a New York Times article posits that, "the threat is coming from a more independent, feminist type of jihadist, who sees herself as acting similarly to a man." Her marking as a "feminist" points to her autonomy.

The framing of Muslim women as suspect is also visible in public-policy discourses in western societies. It is most perceptible in the debate over hijabs, niqabs, burkinis, and burkas. From Australian parliamentarians asking burka-wearing women to sit in glassed enclosures in 2014 and the French burkini ban of 2016 to the 2017 ban on the niqab in Austria, Muslim women are increasingly seen as a threat to/in public spaces in the West. Shakira Hussein situates this suspicion of Muslim women in a longer trajectory of suspicion of Muslims, where concerns over halal food certification, construction of minarets, and demographic changes to Muslim populations are often linked to, and interpreted as, the imposition of sharia law. ${ }^{8}$ As a collectivity, then, Muslims have become a hidden enemy, and Muslim women who were earlier spared such characterization, are no longer immune to it. This trend is producing what Hussein calls (drawing on Mahmood Mamdani) the "Good Muslim Woman/Bad Muslim Woman" binary, where the latter joins 
extremists on the battlefields while the former keeps Muslim men in check, nurturing them to become docile, patriotic citizens, and even government informants.

Against this background, the figure of the Muslim girl as a subject in-themaking, has emerged as an ideal site for training and protection not only for the international development regime but also for the nation-state. This young Muslim girl, if properly educated, can be transformed into the "Good Muslim Woman." Thus, in addition to an economic logic that seeks to shape girls into labor, consumers, and entrepreneurs, there is an ideological and political logic attached to girls' education as well. Indeed, it is argued that Muslim girls can be valuable to countering violent extremism (CVE) in their own societies. Muslim girls are now being called upon to produce counternarratives (particularly online) to resist the propaganda of terrorist organizations. An example of this is the Kofi Anan Foundation's recent Extremely Together campaign, ${ }^{9}$ which brings together ten young activists from countries such as Syria, Somalia, Nigeria, Pakistan, the United Kingdom, and the Philippines. The foundation sees its work as "creating a generation of young activists ... [as] adept at fighting hate speech online as the extremists are at spreading it." ${ }^{10}$ Such programs construct young people as the bulwark against violent extremism.

The treatment of Naureen Leghari in Pakistan is yet another example of how the state deploys itself as the caretaker of girls and how young people are increasingly positioned as being responsible for addressing violent extremism. Leghari, a nineteen-year-old married woman was arrested after a police encounter in Lahore. It is reported that she was radicalized, had traveled to Syria to join Daesh, and had returned to Lahore to join her husband and the militant network. ${ }^{11}$ On April 15, 2017, she was arrested during a raid. What is interesting, however, is the way in which this episode unfolded. Even though she was guilty of being a member of a militant network, she was released. Her culpability was erased through references to her as a student, larki (girl), beti (daughter), bachi (girl-child), and quam ki bachi (nation's girl-child). During a press briefing held in April 2017 by InterServices Public Relations, which is the media wing of the Pakistan Armed Forces, the director general, before playing her confession video, introduced her as "our own girl-child, the nation's girl-child [hamari apni bachi hai, quam ki bachi hai]." After the video, he noted, "The reason for showing you this video confession is that these children are our children. The youth surge is our strength." ${ }^{12}$ Later, in another press briefing in May 2017, the director general used familial language to mark Leghari as the nation's daughter (beti), and installed the army as the caretaker of the nation and its inhabitants:

We recovered Naureen Leghari from Lahore. She is a nineteen-year-old girl. We also showed an interview with her on media. Naureen Leghari was on her way to becoming a terrorist. She was not a terrorist. She was incited ... her immature/young [kam-umar] brain was ... she was brain-washed, which was not right. . . And, we saved her in time. ... Now, if she was my daughter or your daughter [beti], and if we 
save her from being used per the design of terrorists ... then should we punish her like a terrorist? Or should we give her a chance to go out and tell our other young generation about how she was instigated ... and how she was used wrongly ... parents should be aware, institutions [need] to be aware and we [should] use her in our society for correction. We shouldn't punish her. Let me tell you more. In Swat, when radicalization and extremism was underway, Taliban had also taken young children there and brainwashed them. We took many of those children later on when they were free (after the military had rescued them). If we send them to jail then afterward will they become good citizens or will they work against Pakistan? We sent them to a deradicalization center, we brainwashed them positively, told them about being Pakistani [Pakistaniyat] and today, after three to four years, they are good citizens, they earn for their parents, go to school, go to colleges, and contribute to Pakistan. So with regards to Naureen, I would like to say [the same] . . to tell our male and female children [bachay aur bachiyan] about threats they face, how her brain was damaged. ${ }^{13}$

Even though there was evidence that Leghari received training to use weapons, and she explained in text messages to her brother that she had "migrated to the land of Khilafah [caliphate]," ${ }^{14}$ she was viewed as an immature girl, not really in control of her actions. Her gender, biological age, and status as a student were emphasized by the army to transform her from an agentic subject to a tool used by terrorists. She, therefore, deserved protection and not punishment.

This example shows how the figure of the Muslim girl has become a productive site, functioning across multiple discursive networks and authorizing a range of entities and discourses. However, the rise of the figure of the Muslim girl does not mean that tropes about Muslim women's oppression and silence have lost their potency. To the contrary, they continue to have robust political function, in specific moments. Muslim women's oppression and assumptions around Muslim men's violence continue to be utilized to establish the superiority of western civilization, and mark Muslims as having a unique propensity to both engage in violence and tolerate harm done to female bodies (as we have seen in President Trump's 2017 executive orders banning Muslims). What is different now is the availability of diverse Muslim feminine figures through which multiple political ideologies are advanced.

\section{MUSLIM WOMEN'S ACTIVISM}

To disturb present-day certainties about Muslim women of the past as silent victims of patriarchy/Islam/Muslim men, I have engaged with an archive that paints a different picture. While I draw on women's magazines such as Ismat, Khatun, and Tehzib-e-Niswan to explore the debates about education at that time, I also read these writings as autobiographical and argue that they give us a glimpse into women's lives. In fact, if we consider the range of writings that appeared at the turn of the twentieth century, from these magazines and novels to travel narratives, 
reformist texts, cookbooks, and manuals for childcare, housekeeping, and personal hygiene, we get a markedly different picture of Indian Muslim women when compared to their dominant representation as secluded and silent. Indeed, as feminist scholars Leigh Gilmore and Elizabeth Marshall note, women of color have used the autobiographical genre to talk back to the constructions that mark them as permanently vulnerable, ${ }^{15}$ and hence such texts are "an important and yet under-theorized area of feminist resistance." ${ }^{16}$ In these texts, women emerge as thoughtful, engaged, and politically active, even as they struggle within the constraints imposed by patriarchal structures.

Consider Muhammadi Begum and Wahid Jahan, both of whom belie the dominant image of Muslim women of the past. Muhammadi Begum was literate and had a thriving writing and editing career; Wahid Jahan was an author and an adept administrator who ran a women's Normal school and then a hostel. Likewise, Bibi Ashraf strategized her own education and went on to become a teacher in an English school. ${ }^{17}$ In the pages of women's magazines, we find evidence of women who are active and engaged in their political and social milieu-women took up the roles of editors, teachers, writers, fundraisers, and political workers. Indeed, being the official journal of the All India Muhammadan Education Conference, Khatun is teeming with such evidence. The second issue of Khatun, published in 1906, provides details of the ladies conference that was organized in Aligarh on December 28, 1905, by Mrs. Mushtaq, the daughter of Nasr-al-Baqir, Miss Nasiruddin Haider, and Mrs. Raza Allah. The conference was attended by forty bibiyan (sharif women), none of whom were from Aligarh, which meant that they had to travel to the conference. During the conference, Zahra Bint Faizi was named the first president. Elsewhere, in Tehzib-e-Niswan, we learn about the "Tehzibi Fund," to which women regularly sent monetary contributions that were used as prize money for girls to encourage them to go to school in Lahore. ${ }^{18}$ Women were also engaged in the reform movements and were not shy about sharing their discontent with male leadership. In the 1907 issue of Khatun, ${ }^{19}$ for instance, A. W. J. Begum, from Delhi, wrote:

\footnotetext{
I have heard a lot of noise about the fact that the quest for knowledge has not reached Muslim women, and that they are not interested in education in any way. People make speeches at meetings and write articles in newspapers. ... But if you ask them what they have done to spread knowledge among women ... the answer is simply nothing. Everyone says that our gari [vehicle] will reach its destination, but no one seems to be willing to hitch it to an engine, or a horse, or even a bullock, and then everyone regrets that the cart is still sitting in one place. If this keeps up, we will never get anywhere. ${ }^{20}$
}

There is also a sense of solidarity among women, which is apparent in the letters they wrote to each other, sharing personal information and seeking advice. The phrases Tehzibi behnain (Tehzibi sisters) and Ismati behnain also attest to that. 
What we have here is evidence of elite Muslim women's active engagement in securing reforms for themselves even as the limits of such activism were defined by men. Muslim women were, indeed, speaking - in the periodicals and didactic novels, at rallies, and during meetings of political associations.

While the periodicals give us insights into women's lives, it is only the ashraf women whose lives we can learn about through them. Poor and illiterate women did not write in the periodicals. When poor women do make an appearance in the periodicals or didactic novels, it is often as caricatures. Figures such as mama, who appeared in Muhammadi Begum's writings, or the hajjan in Nazir Ahmed's work, belonged to the working class. They are portrayed as helpful and skillful but also clever and conniving. Ashraf women were, thus, directed to maintain their distance from them. There are, however, hints of how working-class women were more effective at managing their employers' affairs given their greater exposure. Since they were not restricted to the zenana like their ashraf counterparts, these women had greater mobility and exposure to the opposite sex. This often meant that they were adept at tasks such as negotiating loans and interest rates, managing domestic budgets, and maintaining social relations (as both mama and hajjan appear to do). Thus, reading the periodicals and didactic novels against the grain can be an effective strategy to learn about some aspects of the lives of poor women at the turn of the twentieth century. However, such a project will always be limited in scope.

During the political movement for Pakistan, a large number of women were mobilized. This included not only elite women but also middle-class women who joined the Muslim League, which actively courted women to support its activities. Jinnah, for instance, noted that "no nation [could] make progress without the co-operation of its women. If Muslim women support their men as they did in the days of the Prophet of Islam, we should soon realise our goal." ${ }^{21}$ Sarah Ansari observes that Jinnah's involvement in the passage of the Shariat Application Act of 1937 (which targeted the customary laws that deprived women of their inheritance rights in relation to immovable property), and the Muslim Dissolution of Marriage Act of 1939 signaled to women that the Muslim League would offer a nation where their conditions would improve. ${ }^{22}$ During the civil disobedience movement of 1946-47, therefore, women took to the streets, participated in public protests and picket lines, hoisted flags on British buildings and got arrested. Fourteen-year-old Fatima Sughra climbed up the gate of the Secretariat Building in Lahore, removed the Union Jack, and replaced it with a duptta. ${ }^{23}$ On April 3, 1947, fifteen hundred Pathan women from the North Western Frontier Province protested publicly. ${ }^{24}$ The nationalist movement, hence, radically changed the parameters of women's participation-women could cast off the veil, talk to strange men, protest on streets, endure tear gas and batons, go to jail, and fight for political seats. Even though men set the terms of women's involvement in this struggle, it is noteworthy that women came out in large numbers to participate in the endeavor. 
After the establishment of Pakistan, while the state again asked women to participate in the development of the nation, this participation was circumscribed by assumptions about their naturalized (gendered) abilities. The primary activist projects that were deemed appropriate for women at that time concentrated on "social work" - addressing the needs of the refugees who had migrated from India, the homeless, widows, and children. This extended women's responsibilities in the public without seriously threatening the status quo. That said, women from elite families continued to fight for political rights-the first legislature of Pakistan, for instance, had two women representatives. In 1948, when the Shariat bill, which recognized women's right to inherit property, was removed from the agenda of the Assembly, women legislators took up the cause with the Muslim League Women's Committee, and effectively protested to get it reinstated. Hence, women pushed on the political fronts where they could. Upper-middle-class women also formed organizations such as the All Pakistan Women's Association and Women's Action Forum, which organized for women's rights and stood up against military rule.

In rereading women and girls of the past as political agents, I do not intend to minimize their suffering or erase the class dynamics of this activism. Indeed, this book has been a story about how women and girls are constrained not only by colonial logics and state practices but also by respectability and class politics. Yet, this subjection is never absolute. Muslim girls and women have found ways within patriarchal and capitalist constraints to secure spaces to breath. Such an understanding of women's lives offers ways for scholars and practitioners alike to move away from interpreting Muslim women's lives in absolute terms-as either always-oppressed or free, always-silent or empowered. Instead, they point to how different social forces regulate the lives of women as well as how women who suffer, resist, strategize, withdraw, and overcome, are crucial players in such stories. Furthermore, such readings make it possible to hold accountable forces that are both external as well as internal to Muslim societies that shape women's lives. In other words, it becomes possible to critique colonial and now imperial and corporate feminism's exploitation of Muslim women, while simultaneously calling attention to the debilitating effects of local forms of patriarchy and state practices that constrain them.

\section{ONLY MIDDLES ...}

Foucauldian genealogies do not have beginnings or ends; thus, this book will also not provide any neat conclusions. Rather, I have traced overlapping storylines and move between the past and the present to signal that we are very much in the middle of stories - stories about the preservation of class privileges, of changing norms of respectability, of exploitation of women's labor, of fluid gender categories, and of activism and political agency. These stories are ongoing as gender and education continue to be powerful discursive fields that regulate the lives of both 
men and women. Our task, therefore, is to constantly subject naturalized categories and social projects to an interrogation as they crystalize particular powerknowledge relations.

This book, I hope, has accomplished at least a couple of objectives. First, it should give pause to practitioners and advocates of girls' education, particularly those from western contexts embedded within the aid-industrial complex. It calls on them to avoid abstracting girls and their education from broader concerns related to social class, domestic and foreign politics, and missionary impulses of international development. Significantly, it problematizes education's emancipatory promise by showing how schooling can reinscribe old hierarchies and/or produce new ones. Hence, any effort towards girls' education must account for the entrenched and systemic subjugation of girls and women across multiple social spaces. Otherwise, schooling and its attendant rewards of participation in the labor force only add additional burdens to the lives of girls.

The second objective is to amplify women's resilience and political agency, while highlighting how women's actions have always been severely constrained. Be it limited access to literacy and capital for publishing during the turn of the twentieth century, or the systematic discrimination by the state and the formal and informal attempts to demarcate women's domains today, women have exercised choice and empowerment within contexts that limit their possibilities. The political stake of this book, then, is to rally allies who are interested in empowering girls to not focus simply on education and waged labor, but to also critically analyze the underlying conditions of women's subjection-a move away from the servicedelivery model and toward a more politicized feminism.

Finally, I hope that this book will pique the interest of researchers in engaging in deeper studies of Muslim masculinities. With the extensive focus on Muslim women and girls within aid and development regimes, there is limited engagement with the representations of Muslim men or complex enactments of masculinities. As this book has shown, particular spatialities are marked as masculine and the masculinizing impulses of the state are often expressed through the infantilization of adult women. Tracing masculinities, masculinizing practices, masculine posturings, and representations of Muslim men thus appears to be a worthy endeavor for future research. 